\title{
CASE COMMENT: RETRoACTIVITy, Social Obligation ANd ChiLd SUPPORT
}

\author{
LUCINDA FERGUSON
}

\section{INTRODUCTION}

The Supreme Court of Canada recently heard argument on the circumstances in which retroactive child support orders are justified. The claimants are four Alberta fathers who have been held subject to retroactive support obligations that extend to before the custodial parent's application for variation of the existing order.' The fathers argue that these orders are unfair and not justified by the Federal Child Support Guidelines. ${ }^{2}$ Supporting their argument is the position of courts in British Columbia, Ontario and Saskatchewan; ${ }^{3}$ these courts have adopted a more restrictive interpretation of the circumstances that justify retroactive orders than has the Alberta Court of Appeal.

This brief comment addresses the critical theory issues before the Court. First, is it the obligation or merely the extent of the obligation that is retroactive? Is the idea of retroactivity in the context of the child support obligation a misnomer? Second, what is the nature of the child support obligation? Third, and consequently, in what circumstances is a retroactive order justified?

\section{RETroactivity: A Misnomer?}

Justice Weiler's comments in the Ontario Court of Appeal decision in Marinangeli highlight the paradoxical nature of the issue before the Supreme Court of Canada:

The decision to award retroactive support is one to be exercised sparingly. In relation to child support the tern retroactive may be somewhat of a misnomer since the obligation to pay support arises immediatcly upon the birth of the child and continues regardless of whether or when the payee spouse brings an action for support.

-
Assistant Professor, Faculty of Law, University of Alberta.

D.B.S. v. S.R.G. (2005), 361 A.R. 60, 2005 ABCA 2, luave to appeal to S.C.C. granted [2005] S.C.C.A. No. 100 (QL) [D.B.S.]; L.J.W. v. T.A.R. (2005), 249 D.L.R. (4th) 136, 2005 ABCA 3, rev'g [2003] A.J. No. 1243, 2003 ABQB 569 (QL), leave to appeal to S.C.C. granted [2005] S.C.C.A. No. 10I (QL); Henry v, Henry (2005), 357 A.R. 388, 2005 ABCA 5, affg (2003), 344 A.R. 377, 2003 ABQB 717. leave to appeal to S.C.C. granted [2005] S.C.C.A. No. 118 (QL); Hiemsirav. Hiemstra (2005), 363 A.R. 281. 2005 ABCA 16, afrg (2005). 44 Alta. L.R (4th) 315. 2005 ABQB 192, leave to appeal to S.C.C. granted [2005] S.C.C.A. No. 128 (QL). The four appeals to the Supreme Court of Canada are being heard together.

$2 \quad$ S.O.R. 1997/175, made under the Diworce Acr. R.S.C. 1085 (2d Supp.), c. 3 [Guidelines]. For comments by the fathers" lawyer, see c.g. "Supreme Court reserves on child support case" Canodion Press (14 February 2006), online: CTV.ca <www.ctv.ca/servledArticleNews/story/CTVNews/ 20060213/scoc_child_support_060213/20060213\%hub=Canada $>$.

See e.g. Park v. Thompsm (2005), 77 O.R. (3d)60I (C.A.) [Park]; Walsh v. Walsh (2004), 69 O.R. (3d) 577 (C.A.); Marinangeli v. Marinangeli (2003), [2004] 66 O.R. (3d) 40 (C.A.) [Marinangeli]; Lahaye v. Dyck (2005), [2006] I8 R.F.L. (6th) 186, 2005 SKQB 267; L.S. v. E.P. (1999). 175 D.L.R. (4th) 423, 199 BCCA 393; Ilubbard v. Gore-Hickman, [200S] II W.W.R. 489, 2005 SKQB 265. 
Justice Weiler's second comment seems to undermine her first statement, if the former accurately characterizes the child support obligation. If a support obligation has existed from the child's birth, how can there be any meaningful discretion to exercise in awarding retroactive support?

This posited realm for discretion only makes sense if we can justify separating out, on the one hand, the underlying nature of the obligation (justifying the support obligation's very existence) from, on the other hand, the quantum of that obligation in practice. But such a move lacks a theoretical foundation. Imagine that we conclude, following our theoretical inquiry, that the child support obligation is grounded in a child's needs. Imagine further that the standard of living of the child at issue was below average, but that her father's earnings were significant. If there were a discretion to award retroactive support, one would need to argue that, despite need being the basis of the support obligation, the extent of the obligation could justifiably exceed the child's needs and enable the child to be provided with a very comfortable life. In relation to an order for retroactive support, the corresponding order would be an award for support to a level that would have, at the time, financed this enhanced standard of living, regardless of whether it now appears to be a windfall. Yet this approach makes no sense. If the level of retroactive support ordered exceeded the child's past needs, the underlying basis for the support obligation itself cannot sensibly be said to be needed.

In this way, the extent of the child support obligation - the level of support that can justifiably be awarded - is built into the basis of the obligation itself. There is no inherent discretion as to quantum contained within the support obligation. Later in this comment, I return to the issue of whether there are any other arguments, such as policy-based reasons, that may, in particular instances, justify not imposing the extent of the obligation suggested by its basis. If I am right that the underlying nature of the support obligation at least prima facie determines its extent, it becomes critical to discern the basis of child support, and it is to this issue that I turn next.

\section{The Social Basis of THE Child Support Obligation}

We can distinguish obligations we owe to the state from obligations we owe to other citizens. The latter category contains both general and special obligations. ${ }^{5}$ General obligations are those that we owe to other people simply because they are people. Special obligations, by contrast, are owed only to particular persons with whom we stand in certain specific relationships. So we owe a duty to provide emotional and financial support to a spouse that we would not owe to a stranger suffering from identical hardships. A parent's obligation to provide financial support to her child or children is generally understood as a special obligation. She owes an obligation to provide financial support that she does not owe to her neighbour's children, to children she sees in the grocery store or to children appearing in television appeals for natural disaster relief funding.

- For an introduction to the idea of special obligations generally, see Samuel Scheffler, Boundaries and Allegiances: Problems of Justice and Responsibiling in Liberal Thought (Oxford: Oxford University Press, 2001), especially cc. 3, 6 (here: "general duties" and "special duties"). Contrast Erin Kelly, "Personal Concem" (2000) 30 Canadian Joumal of Philosophy 115 . For an introduclion to these issues in the family context, see Diane Jeske, "Families, Friends, and Special Obligations" (1998) 28 Canadian Joumal of Philosophy 527. 
Diane Jeske contends that "[m]ost of us accept that we have special obligations to our family members: to, e.g., our parents, our siblings, and our grandparents. But," she continues, "it is extremely difficult to offer a plausible grounding for such obligations, given the apparent fact that (at least most) familial relationships are not voluntarily entered." Jeske notes parenthetically that spousal relationships and the relationship between parents and their children are obvious exceptions to this general difficulty.

It is by no means obvious, however, that the voluntarist argument underpins the child support obligation. While not the majority, there are certainly a number of fathers who did not intend to father the particular child in question; is it enough that they intended to engage in the act of procreation? What if an individual thought that he had taken sufficient precautions to ensure that no pregnancy would result? What if he was deceived by his partner as to what precautions had been taken? These situations could be said to be the exception that proves the voluntarist rule, yet they also cast doubt on the force of the voluntarist argument for the child support obligation.

Further, it may not make any difference whether we accept the voluntarist contention for the basis of the support obligation. It may not make any difference because any voluntarist explanation cannot be the entire explanation. ${ }^{8}$ Even if we understand the act of procreation as tacit consent to support any children that might be born as a result, this still fails to reveal the nature of the support obligation. Why should we treat consent to sex as consent to child support? Scott Altman suggests that one answer might be based in the idea of fair notice: "Most people asked to pay support knew or should have known that they assumed such a risk by having sex." But, as Altman notes, "widespread notice of a custom (such as assignment of support duties to parents) cannot truly justify the custom." Altman is surcly right, yet this argument is useful to the extent that the element of the social in the fair notice model suggests a better way to understand the basis of the support obligation.

If we cannot meaningfully consent to a support obligation, yet we still generally feel that ourselves and others are bound to support any children we bring into the world, this suggests that the obligation has a social nature." We can test this by contrasting the position in our society with that in other societies. Imagine that research revealed that the outcomes for children were better if they were raised in boarding school-style environments from a very young age, rather than in families. Imagine further that, as a result of this research, we invested very heavily in creating these ideal rearing environments that were accessible to

- Jeske, ibid. at 527.

$7 \quad$ Ibid. at n. I. See also Onora O'Neill, "Begetting, Begging, and Rearing" in Onora O'Neill \& William Ruddick, eds., Having Children: Philosophical and Legal Reflections on Parenthood (New York: Oxford University Press, 1979) 25.

* This point does not hold for many other special obligations. In relation to obligations owed between spouses (including spousal support), for example, the parties' interactions offer many alternative aceounts of the nature and extent of any obligation owed. The asymmetrical relationship between parent and infant child forestalls a similar argument in the child support context.

- Scott Aliman, "A Theory of Child Support" (2003) 17 Int'l J.L. Pol'y \& Fam. 173 at 180.

$10 \quad$ lbid.

"In The Concept of Law, 2d ed. (Oxford: Clarendon Press, 1994), H.L.A. Hart understands one sense of morality - moral duties - to be understood through the practices of a particular social group. For discussion, see John Eekelaar, "Are Parents Morally Obliged to Care for Their Children?" (1991) 1 ! Oxford J. Legal Stud. 340, especially at 342. 
children from all socio-economic backgrounds. In this situation, would we feel, as we do in our current society, that parents are obliged to provide support for their children? I would suggest not; instead, we would likely feel that it was the responsibility for parents to make sure that their children were enrolled in these programs, rather than remaining at home.

This example illustrates two points. First, any perceived obligation is underpinned by moral duty. We are all under a moral duty toward others in general to promote human flourishing. ${ }^{12}$ In relation to children, this expresses itself as a duty to ensure that children are raised in a way that enables them to reach adulthood with maximal opportunities for the future. In both social arrangements discussed in the hypothetical, we are under a duty to ensure children flourish. Second, it is the available mechanisms for achieving this result that distinguishes the two scenarios. Social practice determines how this moral duty finds its expression in particular societies. Social practice thus shapes any social obligations, hence also legal obligations owed.

The social practice that parents support and raise their children thus creates the dependency of children on particular adults - their parents - for provision of this financial support. As John Eekelaar argues, "[d]ependency ... may arise from the operation of social norms as much as from brute fact."13 Social practice in this sense determines social obligations, which in turn become legally enforceable in the event that the obligees deviate from the default position of an intact family.

While the idea of a social norm makes sense for the majority of individuals who associate with their role as parent and feel obligated to provide that financial support, ${ }^{14}$ what about the parent who does not feel obligated to pay? Why is it justifiable to enforce social obligations against individual citizens who do not wish to be bound by those obligations? I suggest that it is because, once we have selected particular social rules to give best effect to our moral obligations in particular situations, the enforcement of these social obligations against those who do not identify with them fulfils our own moral duty toward children. This makes sense if we recall the priority of our moral duty to these social obligations: it is our moral duty to enable children's flourishing that underpins any social obligations of support.

Just as the existence of the child support obligation is based on the social obligation of parental liability for financial support for their children, its extent also is determined by that same social obligation. The social obligation is framed around the ideal parents. The ideal parents would provide for more than their children's needs, means permitting. Hence, the social obligation enforced against non-custodial parents obliges them to support their children to the extent that the ideal parent would - as specified by the Guideline amounts.

12 Eckelaar, ibid. at 351. Sec Aristolle, Nicomachean Ethics, trans. by Christopher Rowe (Oxford: Oxford University Press, 2002), on virtue theory. While the idea of "human flourishing" is difficult to define in many contexts, the minimal content in relation to children and their development into adults seems less controversial.

13 Eekelaar, ibid.

14 For a more detuiled argument from the idea of role obligations, sce Michael O. Hardimon, "Role Obligations" (1904) 91 Journal of Philosophy 333. 
This analysis helps explain the position taken by the Alberta Court of Appeal. In D.B.S., ${ }^{15}$ for example, the court ordered retroactive support for a period of 36 months preceding the motion brought by the mother in court. Given the insufficient financial records before the court, the case was returned to the chambers judge to determine the extent and manner of any support owed. In her judgment for the court in D.B.S., Paperny J.A. understood the context of the Guidelines as follows:

In the post-Guidelines era, there is a clear recognition that child support is a joint obligation and that child support orders are intended to ensure that each parent pays his or her fair share. Thus, the focus is no tonger on need (which is assumed); is is instead now characterized. amd properly so, as entillement. ${ }^{16}$

Justice Paperny also argued that there is no requirement for formal notice to the payor before the court can find an entitlement to retroactive support, and that it was inconsistent with the Guidelines to require that there be exceptional circumstances before awarding retroactive support. If these three points are taken together, the theoretical basis for the decision reached in D.B.S. becomes clear.

If the child support obligation owed is a social obligation that arises at birth, the father should have known of the obligation and its crystallization into a legal obligation after separation. This father cannot use the issue of notice or the need for exceptional circumstances to reduce his obligation. When the Guidelines ushered in the entitlement perspective, and its ideal parent calculation of quantum, there was a shift in the nature of the social obligation owed. The very structure of the social obligation and its grounding in our underlying moral duty, as discussed above, estops this father from arguing that he cannot be bound by it. Thus, the Alberta decision is supported by my argument for the theoretical basis of the child support obligation.

On the theoretical model I have developed here, retroactive child support awards can be justified in more than exceptional circumstances; retroactive awards can be justified to extend back to any point at which there is a clear shift in social norms, here the introduction of the Guidelines. However, the prima facie justification of invasive obligation does not necessarily mean that the obligation should be imposed in every circumstance in which it exists; valid policy reasons may defeat this prima facie justification.

\section{The APpropriate Role for POLiCy Considerations}

The proper role for policy considerations in relation to the child support obligation is a very interesting question. While child support is an interpersonal obligation, it must be distinguished from other interpersonal obligations, such as spousal support, liability in tort for negligence, liability for breach of contract and so forth, which are created by the parties' interactions. The asymmetry of the relationship between parent and child at the moment of the inception of the obligation distinguishes child support. 
This is also reflected in the social nature of the obligation owed. Thus, if particular policy grounds for not freely enforcing retroactive support against non-custodial fathers can be said to improve the ability of that social obligation to meet our moral duty, there may be good reason not to enforce the prima facie retroactive obligation in particular cases or types of cases.

The Ontario Court of Appeal decision in Park ${ }^{17}$ provides a good example of policy grounds that might be held to mitigate against a retroactive order. Justice Rosenberg set out the following mitigating factors:

(1) the order would cause an unreasonable or unfair burden to the non-custodial parent, especially to the extent that such a burden would interfere with ongoing support obligations;

(2) the only purpose of the award would be to redistribute capital or award spousal support in the guise of child support; and a significant, unexplained delay in bringing the application. ${ }^{18}$

In Park itself, Rosenberg J.A. set aside the order for retroactive child support on two grounds: first, that the delay in bringing the application was unreasonable - a delay of 13 months from when the father first refused to make further child support payments to the date of the application. Second, a retroactive order would impose significant burdens on the father, especially given his responsibilities to his new family and the fact that the mother had not had to encroach on capital or incur debt in order to support the child during the period for which a retroactive order was sought.

The difficulty lies with the application of any accepted policy grounds for not enforcing retroactive support. If the Guidelines approach is premised on the idea of the child's entitlement, why should it matter whether the mother had to encroach on her own savings or go into debt in order to support the child? Is the child not entitled to whatever better standard of living the increased funds from her father would provide?

Similar issues arise in relation to the issue of delay. In Park, the father knew he was under an obligation to pay child support; indeed, he had been paying support, but then prematurely ceased making these payments. If child support is an obligation to the benefit of which the child is entitled, why should the child be penalized for any delay on the mother's part in bringing a claim? The importance laid on the delay in Park is especially difficult to understand, given that the separation agreement itself made it clear that an application for support under the Guidelines could follow as a result of failing to make the support payments set down in the agreement.

This brief exploration of the place of policy arguments in relation to child support, particularly retroactive child support applications, suggests that the logic of the social obligation of the Alberta model of support undermines the validity of the policy reasons taken into account by the courts in other provinces. This is not to say that no policy reasons 
will ever justify dismissing an application for retroactive support, but that it is not yet clear what those reasons might be.

\section{Conclusion}

In looking at the underlying theoretical justification for child support and retroactive child support orders, this comment has sought to introduce some of the bigger questions that the Supreme Court of Canada ought to be addressing when deciding the Albertan fathers' appeal. A theoretical analysis of the case reveals that the Alberta Court of Appeal's construction of child support is justifiable as a social obligation, rooted in our moral duty to promote human flourishing. The unresolved difficulty is whether, and if so when, policy reasons might outweigh this interest in imposing and enforcing a retroactive support obligation. The theoretical debate presented here has enabled us to step back from the debate around fairness to the fathers and mothers involved and to focus on the child and his or her entitlements. If the Supreme Court of Canada keeps the child at the centre of its reasoning, we might hope for a similar result. 